\title{
Definition of priority areas for soil and water conservation in the Itanguá watershed, Capão Bonito, SP state, Brazil
}

\author{
Definição de áreas prioritárias à conservação de solo e água na bacia do Itanguá, \\ Capão Bonito - SP, Brasil
}

\section{Mariana Santos Leal', Herly Carlos Teixeira Dias ${ }^{\mathrm{II}}$, Rafael Mingoti ${ }^{\mathrm{III}}$, Marcos Paulo Ferreira $^{\mathrm{IV}}$, Kelly Cristina Tonellov}

\begin{abstract}
The improper soil use may lead to erosion and silting of watercourses, reducing the quantity and the quality of water in the watershed. The implementation of soil conservation practices and the presence of native vegetation are crucial for soil and water conservation in the basin, since they act by decreasing water runoff and erosion. This study aimed to develop a map of priority areas for soil and water conservation in the Itanguá watershed, Capão Bonito, SP state, based on the characterization of the use and land cover and slope of the basin and, define areas with a high need to implement conservation practices. For the creation of thematic maps with the information plans of land use, land cover and declivity were combined by the Boolean method on a geographic information system. After the analysis, it was found nine different priority classes for the implementation of conservation practices and six priority classes for forest restoration in the permanent preservation area. Areas with a dirt road in a region of higher declivity were identified as priority areas for conservation, including the permanent preservation area along watercourses in the basin. The study provides the first assessment of the land use and land cover at the basin level for Capão Bonito National Forest and provides a basis for identifying conservation priorities across the Itanguá basin.
\end{abstract}

Keywords: Capão Bonito National Forest; Forest restoration; Permanent preservation area

\section{Resumo}

O uso inadequado dos solos pode provocar erosão e assoreamento dos cursos d'água reduzindo assim a quantidade e a qualidade da água na bacia. A implantação de práticas conservacionistas de solo e a presença de vegetação nativa são ações de fundamental importância para a conservação do solo e água na bacia, uma vez que elas atuam diminuindo o escoamento superficial da água e os processos erosivos. Dessa forma, este estudo teve como objetivo desenvolver um mapa de áreas prioritárias para conservação do solo e da água na bacia hidrográfica do Itanguá, Capão Bonito - SP, com base na caracterização do uso e cobertura do solo e declive da bacia e definir áreas com alta necessidade de implementação de práticas de conservação. Para a elaboração dos mapas temáticos, os planos de informação de uso e cobertura da terra e declividade do terreno foram combinados pelo método booleano em um sistema de informação geográfica. A partir da análise dos dados foram encontradas nove diferentes classes de prioridade para implantação de práticas conservacionistas e seis classes de prioridade para a restauração florestal na área de preservação permanente. Áreas com estrada de terra em região de maior declividade foram identificadas como áreas prioritárias para conservação, inclusive em área de preservação permanente ao longo dos cursos d'água da bacia. $\mathrm{O}$ estudo proporciona a primeira avaliação do uso e cobertura da terra no nível da bacia para a Floresta Nacional de Capão Bonito e fornece uma base para identificar prioridades de conservação em toda a bacia de Itanguá.

Palavras-chave: Floresta Nacional de Capão Bonito; Restauração florestal; Área de preservação permanente

\footnotetext{
Engenheira Florestal, MSc, Programa de Pós-Graduação em Planejamento e Uso dos Recursos Renováveis, Universidade Federal de São Carlos, Campus Sorocaba, Rod. João Leme dos Santos, Km 110, CEP 18052-780, Sorocaba (SP), Brasil. mari_floresta@hotmail.com (ORCID: 0000-00016377-7210)

Engenheiro Florestal, Dr., Departamento de Engenharia Florestal, Universidade Federal de Viçosa, Av. Peter Henry Rolfs, s/n, CEP 36570-900, Viçosa (MG), Brasil. herly@ufv.br (ORCID: 0000-0002-6893-0920)

III Engenheiro Agrônomo, Dr., Empresa Brasileira de Pesquisa Agropecuária - Embrapa Gestão territorial, Av. Sd. Passarinho, 303, CEP 13070-115, Campinas (SP), Brasil. rafael.mingoti@embrapa.br (ORCID: 0000-0003-4873-7565)

Acadêmico de Engenharia Florestal, Departamento de Ciências Ambientais, Universidade Federal de São Carlos, Campus Sorocaba, Rod. João Leme dos Santos, Km 110, CEP 18052-780, Sorocaba (SP), Brasil. mmarcos.ferreira@gmail.com (ORCID: 0000-0001-9930-5960)

Engenheira Florestal, Dra., Departamento de Ciências Ambientais, Universidade Federal de São Carlos, Campus Sorocaba, Rod. João Leme dos Santos, Km 110, CEP 18052-780, Sorocaba (SP), Brasil. kellytonello@ufscar.br (ORCID: 0000-0002-7920-6006)
} 


\section{Introduction}

At the same time, water is considered essential for life, is a natural resource that is currently undergoing great pressures and problems of shortage, both in quality and quantity, in some parts of the world, especially in places close to urban areas and with intensive agriculture practices.

The quantity and quality of water is influenced, in addition to physical factors, by environmental conditions of contribution areas and improper of soil management. These can influence the infiltration and the storage of groundwater, which, in turn, can affect the flow of springs and may also lead to soil erosion and silting of watercourses.

The watershed is an important unit of management, as established by Brazil's Federal Law 9.433/97, because all interventions and impacts that happen not only in the springs, but throughout the basin, can cause changes in the quantity and quality of the water produced.

In order to keep the water stored in the watershed, it is crucial that the forest cover is maintained, for the reason that forest soils contribute to the ability of water infiltration in the soil due to its significant layer of organic matter, higher porosity and aggregation of particles (BERTONI; LOMBARDI NETO, 1990), particularly in Permanent Preservation Areas (PPAs). Unfortunately, as the vast majority of riparian forests are degraded or even absent, they end up not fulfilling their roles of protecting the springs and the watercourses and, therefore, the restoration of these areas is essential for the maintenance of a balanced environment.

On this, enormous and growing environmental problems and a chronic shortage of resources to tackle them require conservationists to set priorities for investment and actions (WILSON et al., 2006; BEGER et al., 2015). Several global conservation prioritisation exercises are undertaken, by a different criterium, relating to soil conservation, water, biological importance, environmental services and others (BUCHANAN; DONALD; BUTCHART, 2011).

Recent reviews give some sensible recommendations on land-use planning within protected and agricultural areas, which include: restoration towards natural forest, designating corridors that facilitate migration of plants and animals, maintenance of diverse landscape mosaics (TAMBOSI et al., 2014) and the adequate management of the water resources, in what refers to areas of water recharge and conservation of springs.

The main drivers of degradation of water resources in watershed are urbanisation processes, intensive agriculture, conversion of riparian vegetation and no use of soil and water conservation practices. Osuna et al. (2014) has priorizated areas for watershed service conservation in Brazil and concluded that some sub-watersheds also happen to exhibit high levels of water resources vulnerability and thus represent potential priority intervention zones for watershed management. In these areas, watershed planners may reap considerable benefits from active pasture management options, such as silvopastoral systems or strategic fencing of riparian areas. In addition, sustainable agricultural and soil conservation practices can bring additional benefits in terms of reducing and avoiding sedimentation, erosion, which in turn result in improving water quality.

In Brazil, 'Capão Bonito' National Forest is located in Paranapiacaba valley, southwestern region of São Paulo state and its main water course is Itanguá stream. It is an important Conservation Unit for Sustainable Use, being an instrument of environmental territorial planning, which also contributes to water conservation. One aspect of this National Forest is that more than $50 \%$ of its territory is occupied by Pinus spp. plantations, aged approximately 50 years old. From a total of 4,344 hectares, 3,489.39 ha are occupied by reforestation, distributed into: 2,402.19 hectares of Pinus elliotti; 39.47 ha of Pinus spp.; 1,002.00 ha of Araucaria angustifolia; 45.73 ha of experiments with several other native tree species and exotic species and the other 270 ha of native forest (BRASIL, 2016). Currently, the management council discusses the revision of the management plan of 'Capão Bonito' National Forest, the main management tool of the Conservation Units. So, better techniques of forest management and the adequacy of the use 
and occupation of the soil were taken in order to promote a better management of its natural resources.

The objective of this study was to develop a map of priority areas for soil and water conservation based on the characterization of the use and land cover and slope of the Itanguá basin and, so, indicate the possible conservation practices to be adopted to promote the sustainable water resource management.

\section{Material and methods}

\section{Study area}

The basin of Itanguá stream has a total area of $28.3 \mathrm{~km}^{2}$ and is located in Serra do Paranapiacaba valley, southwestern region of São Paulo state, municipality of Capão Bonito, between the coordinates $23^{\circ} 54^{\prime}-23^{\circ} 59^{\prime} \mathrm{S}$ and $48^{\circ} 32^{\prime}-48^{\circ} 30^{\prime} \mathrm{W}$. Approximately $60 \%$ of its area is located inside Capão Bonito National Forest (Figure 1).

Figure 1 - Capão Bonito National Forest and Itanguá watershed, Capão Bonito, SP state.

Figura 1 - Floresta Nacional de Capão Bonito e bacia do Itanguá, Capão Bonito - SP.

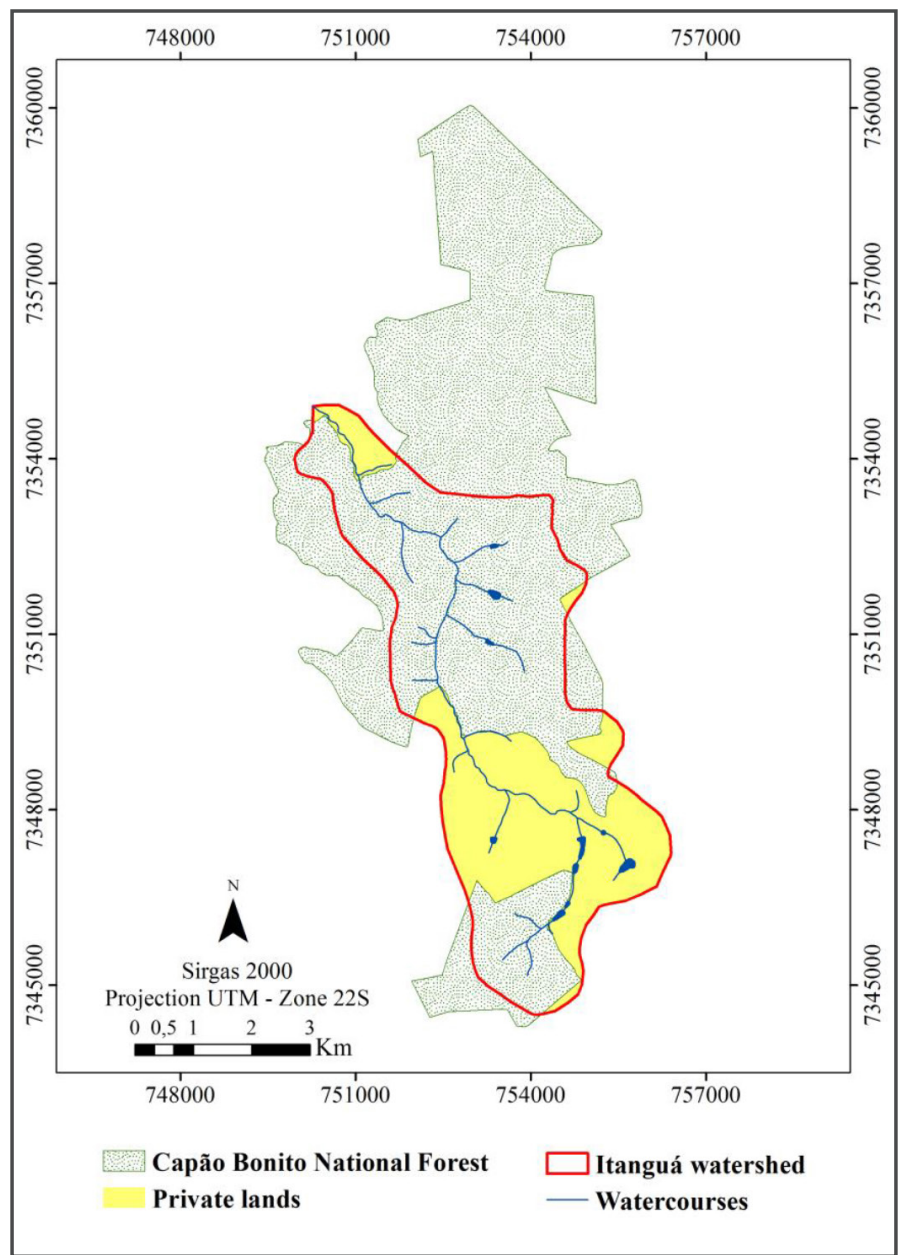

Source: Leal (2016) 
The vegetation of Capão Bonito National Forest is described as Dense Ombrophilous and Savanna, with an altitude of approximately 700 meters and a slightly wavy relief. The average annual rainfall is $1200 \mathrm{~mm}$, with the climate described as Cwa according to the climatic classification of Köppen, with dry winters and rainy summers (CENTRO DE PESQUISAS METEREOLÓGICAS E CLIMÁTICAS APLICADAS A AGRICULTURA, 2016).

The basin flows into Apiaí Mirim River, a tributary of Paranapanema River, one of the most important rivers in São Paulo State, not only for its socio-environmental characteristics, but also for being a border river between the states of São Paulo and Paraná, being classified as the least polluted river in São Paulo state.

\section{Data processing}

The definition of priority areas for both the implementation of soil conservation practices and forest restoration in the PPA was performed using information plans of land use and land cover (FIGURE 2a) and declivity (FIGURE 2b).

For the preparation of the thematic map of land use and cover, it was used an image from Rapideye satellite orbital from the year 2013, with a spatial resolution of 5 meters. The geo-referencing of the image was obtained through the control points with geographic coordinate already known. From this image, in the ArcMap 10.1 software, it was possible to delimitate the area by vectoring on screen using the classes of IBGE (2013). The slope map was also done in a GIS environment using the digital elevation model.

These factors were selected due to its influence on the concentration time of water into a basin and in the hydrological processes of runoff and water infiltration in the soil, since each category of land use and cover provides a different behaviour according to the surface runoff and water infiltration, where the more unprotected the ground is, the more the runoff velocity will be, the disaggregation and the translocation of soil particles.

The hierarchy classes of land cover and land use was performed according to the value of factor C in "The Universal Equation of Soil Loss" (USLE), which corresponds to the soil use and management, varying from zero to one, being closer to zero in conservation management systems, and closer to one in non-conservation systems (BERTOL; SCHICK; BATISTELA, 2002). Therefore, the higher the value, the higher is the priority category for its conservation (TABLE 1).

The declivity classes from 0 to $3 \%$ and $3 \%$ to $8 \%$, according to Ramalho Filho and Beek (1995), have little or no susceptibility to erosion and can be controlled with simple conservation practices; therefore, the priority is lower, adding up $78.85 \%$ of Itanguá basin. According to the same authors, the land with declivity varying from 8 to $13 \%$ is classified as moderated and from 13 to $20 \%$ as having a strong susceptibility to erosion, which requires more intensive control practices, accounting for $14.82 \%$ and $6.32 \%$ of the terrain, respectively.

The lands with declivity ranging from 20 to $45 \%$ have their agricultural use restricted, because of their high susceptibility to erosion, accounting for only $0.01 \%$ of the basin. The classes above these values were not found in the study area. 
Figure 2 - (a) Land use and land cover, (b) declivity of the Itanguá watershed, Capão Bonito, SP state.

Figura 2 - (a) Uso e cobertura da terra, (b) declividade da bacia do córrego Itanguá, Capão Bonito - SP.

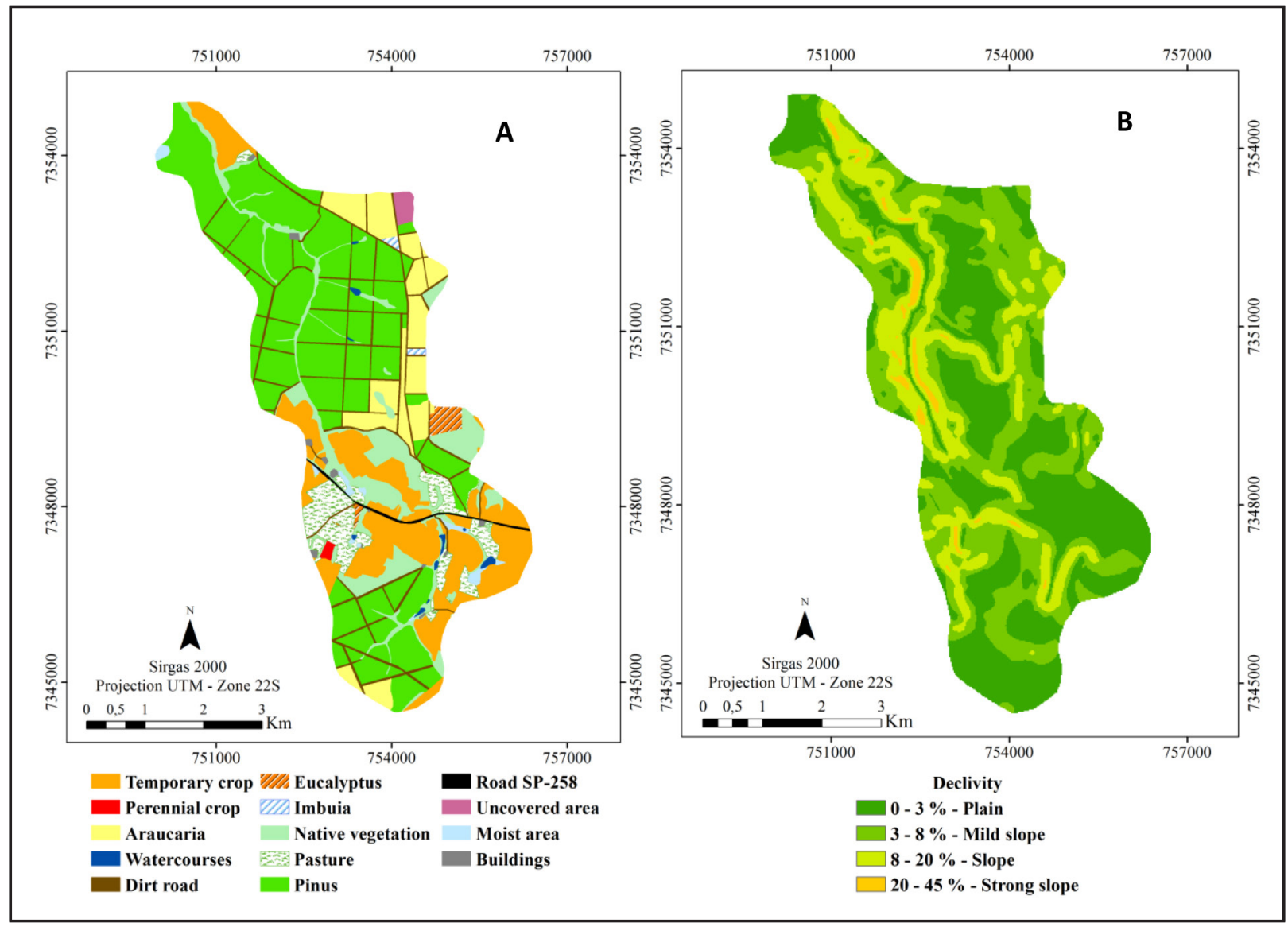

Source: Authors (2016)

Table 1 - Hierarchy of different categories of information plans used in the definition of priority areas for the implementation of soil conservation practices in the basin of Itanguá, Capão Bonito, SP state.

Tabela 1 - Hierarquização das diferentes categorias dos planos de informação utilizados na definição das áreas prioritárias para a implantação de práticas conservacionistas de solo na bacia do Itanguá, Capão Bonito - SP.

\begin{tabular}{llcc}
\hline & & \multicolumn{2}{c}{ Declivity } \\
\cline { 3 - 4 } Land use and land cover & Factor C $^{*}$ & $\mathbf{0 - 8 \%}$ & $\mathbf{8 - 4 5 \%}$ \\
\hline Uncovered areas & & - & $\mathrm{x}$ \\
Dirt road & 0.90 & - & $\mathrm{x}$ \\
Perennial crop & 0.50 & - & $\mathrm{x}$
\end{tabular}

Continued... 
Table 1 - Conclusion...

Tabela 1 - Conclusão...

\begin{tabular}{llll}
\hline & & \multicolumn{2}{c}{ Declivity } \\
\cline { 3 - 4 } Land use and land cover & Factor C* & 0-8\% & 8-45\% \\
\hline Temporary crop & & - & $\mathrm{x}$ \\
Pasture & 0.25 & - & $\mathrm{x}$ \\
Planted forests & 0.25 & - & $\mathrm{x}$ \\
\hline Uncovered area & 0.05 & $\mathrm{x}$ & - \\
Dirt road & 0.90 & $\mathrm{x}$ & - \\
Perennial crop & 0.50 & $\mathrm{x}$ & - \\
Temporary crop & 0.37 & $\mathrm{x}$ & - \\
Pasture & 0.25 & $\mathrm{x}$ & - \\
\hline Planted forests & 0.25 & $\mathrm{x}$ & - \\
\hline Restriction & 0.05 & - & \\
\hline Source: Authors (2016) & - & & \\
* Agência Nacional de Águas (2008). & & & \\
\hline
\end{tabular}

In order to define the priority areas, the categories of land use for Pines and Eucalyptus were grouped into the category of planted forests, due to the fact of being silvicultural systems. As the areas with buildings, road, body water and moist area already have a consolidated use, the Araucaria (Araucaria angustifolia) and Imbuia (Ocotea porosa) for being native species preserved in the National Forest and the native vegetation is already conserving the soil and the water, they were disregarded in the analysis, being classified as restriction.

Even though the Araucaria has been planted in form of plots, it is a native species classified as critically endangered by the International Union for Conservation of Nature and Natural Resources (INTERNATIONAL UNION FOR CONSERVATION OF NATURE AND NATURAL RESOURCES, 2013). According to a previous study carried out in the area, under the plantations of Araucaria angustifolia, 652 individuals with $\mathrm{CBH}$ higher than $15 \mathrm{~cm}$ were sampled, distributed into 93 species, 44 families and density of $1204 \mathrm{ind}$./ha, allowing the natural regeneration to happen in the understory (SCHIEVENIN, 2013).

The information was crossed and then a table with the priority classes found in the area was created. As the categories of land use for temporary crop and pasture showed the same value of Factor C, they were grouped in the same priority class.

In both analysis, the information plans on land use, land cover and declivity were combined through the Boolean logic, creating thematic maps with different priority classes and all data processing was performed in a GIS environment in the QGIS programs 2.8 and ArcMap 10.1. In the Boolean method, the criteria are reduced to logical statements of suitability and combined by means of one or more logical operators, such as intersection and union (EASTMAN, 2001). 


\section{Results and discussion}

\section{Priority areas for the implementation of soil conservation practices}

After crossing the data, the class with the highest priority for the implementation of soil conservation practices was the dirt road in a region of higher declivity. On the other hand, the category with the larger area was the one with priority 9, which corresponds to the planted forests in areas of lower declivity, occupying almost $40 \%$ of the entire basin area, followed by the priority classes 8 and 4 (Table 2).

Table 2 - Priority classes in the basin of Itanguá, Capão Bonito, SP state and their respective areas (in hectares).

Tabela 2 - Classes de prioridade na bacia do Itanguá, Capão Bonito - SP e suas respectivas áreas (em hectares).

\begin{tabular}{|c|c|c|c|c|c|}
\hline \multirow{2}{*}{ Land use and land cover } & \multicolumn{2}{|c|}{ Declivity } & \multirow{2}{*}{ Priority } & \multirow{2}{*}{ Area $($ ha) } & \multirow{2}{*}{ Area $(\%)$} \\
\hline & $0-8 \%$ & $8-45 \%$ & & & \\
\hline Dirt road & - & $\mathrm{x}$ & 1 & 23.34 & 0.82 \\
\hline Perennial crop & - & $\mathrm{x}$ & 2 & 3.12 & 0.11 \\
\hline Temporary crop/Pasture & - & $\mathrm{x}$ & 3 & 162.76 & 5.75 \\
\hline Planted forests & - & $\mathrm{x}$ & 4 & 343.92 & 12.15 \\
\hline Uncovered area & $\mathrm{x}$ & - & 5 & 16.84 & 0.59 \\
\hline Dirt road & $\mathrm{x}$ & - & 6 & 94.00 & 3.32 \\
\hline Perennial Crop & $\mathrm{x}$ & - & 7 & 2.00 & 0.07 \\
\hline Temporary crop/Pasture & $\mathrm{x}$ & - & 8 & 520.32 & 18.38 \\
\hline Planted forests & $\mathrm{x}$ & - & 9 & 964.6 & 34.07 \\
\hline Restriction & - & - & - & 700.2 & 24.73 \\
\hline Total & & & & 2831.10 & 100 \\
\hline
\end{tabular}

Source: Authors (2016)

In addition, a thematic map with different priority classes was created after the data processing on GIS.

The maps produced are important tools in decision-making, collaborating with the management of Capão Bonito National Forest and the surrounding areas of Itanguá watershed.

The Figure 3 allowed the visualization of classes according to their priorities for the implementation of soil conservation practices, where actions should begin, that is, in the most critical sites, so that the basin's conservation increases and thus reduces its degradation activities.

Rosa, Tonello and Lourenço (2016) conducted a similar study in the municipality of Ibiúna, SP state, prioritising areas for the payment for ecosystems services and, according to their observations, this kind of analysis proved to be viable for decision-making. Liu et al. (2013) identified the priority conservation areas for ecosystem services to allow a sustainable urban expansion. The authors modeled and mapped five ecosystem services (carbon storage, timber production, water yield, water-quality improvement and sediment retention) and proposed a definition of priority areas for the conservation of ecosystem services. Priority areas for individual ecosystem services showed that $24 \%$ of the region was needed to produce $26 \%$ of water yield. 
Figure 3 - Priority areas for the implementation of soil conservation practices in the basin of Itanguá, Capão Bonito, SP state.

Figura 3 - Áreas prioritárias para a implantação de práticas conservacionistas de solo na bacia do Itanguá, Capão Bonito - SP.

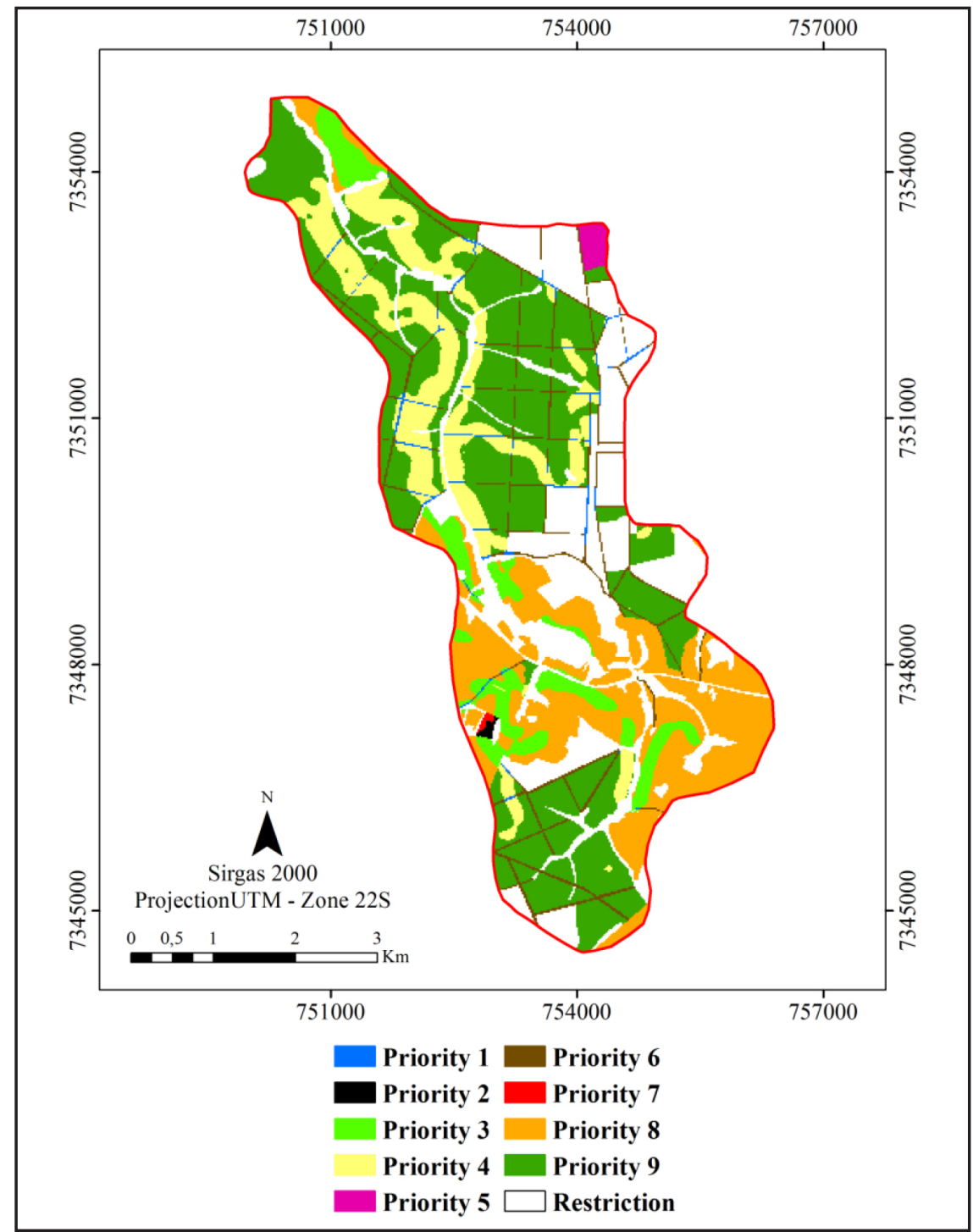

Source: Authors (2016)

The implementation of conservation practices is of great importance for soil and water conservation, because they act by reducing the runoff velocity, providing a higher water infiltration, maintaining soil moisture, improving the aggregation of particles, resulting in the prevention of erosion processes. They may be of mechanical, growth or edaphic nature and can be used isolated or in combination.

The mechanical practices consist of physical barriers, which decrease the flash flood velocity, for instance, terracing, permanent windrowing and basins. The vegetative methods are those that not only reduce the water velocity but also protect the soil against the impact of raindrops, preventing the breakdown of particles, for example, reforestation, mulch, cover crops, strip crops and crop rotation (SILVA; SCHULZ; CAMARGO, 2003). 
The edaphic practices, which consist in soil cultivation according to its ability, can promote the maintenance or the improvement of fertility, as well as its protection. The green manure, organic and liming are some examples of edaphic practices.

In a study conducted in the Federal District, Chaves and Piau (2008) concluded that the type of soil use and its management affected significantly the surface runoff and the amount of sediment carried in the assessed period, obtaining the highest values of flow in areas of conventional tillage when compared to the areas of no-tillage and native vegetation.

The soil cover can be obtained through crop residues left on the surface or by the presence of vegetation. These practices have a direct and effective impact on reducing erosion, because they decrease the impact of raindrops, which in turn decreases the breakdown of soil particles and the sealing surface, increasing the water infiltration (COGO; LEVIEN; SCHWARZ, 2003).

Soil surface protected with crop residues can also reduce wind erosion. Still according to Cogo, Levien and Schwarz (2003), when the authors observed a very clay soil in the region of Missões, Rio Grande do Sul state, they realized that soil losses by water were lower in areas with direct sowing than in areas with conventional tillage. In Lajes, Santa Catarina state, Schick et al. (2000) concluded that crop rotation has reduced soil loss at 37\%, when compared to conventional tillage.

In the Three Gorge Project (TGP) of China combining terraces, contour farming with a seasonal no-till ridge, contour tillage, and crop rotations resulted in the greatest reduction in soil loss with approximately $91 \%$ of the areas with soil loss $>T_{\mathrm{EP}}$ tolerance for economic planning) being reduced to $<T_{\mathrm{EP}}$ with very little financial investment (SHI et al., 2004).

The pastures, in order contribute to soil and water conservation, should be managed in a sustainable manner, otherwise they may impact the watersheds, resulting in negative environmental impacts by reducing the water infiltration and degrading the chemical and physical properties of the soil, leading to erosion processes. A study conducted in a rural property in the region of Marabá in Pará concluded that a degraded pasture decreased soil coverage, leaving it exposed to rain and cattle trampling, which resulted in soil compaction (MULLER et al., 2001).

Planted forests usually have lower erosion values, except if they are disturbed by fire, harvesting and the construction of forest roads, so the practice of logging, which occurs in the National Forest, must be well planned with minimal impacts, because after clearcutting the ground is unprotected, which may increase the runoff velocity, releasing sediments into the watercourses, as described by Oki (2002), resulting in soil and nutrient losses and consequently in soil and water degradation.

The terraces, conservation structures composed of a ridge and a channel constructed perpendicular to the slope, decrease the surface runoff velocity and increase water infiltration in the soil because the water is accumulated in the channel, facilitating its infiltration.

The water retention basin, which promotes the acquisition, retention and infiltration of exceeded water from roads, avoids the damage caused by erosion in its bed and in nearby areas, contributing to the groundwater supply (BERTOLINI, 1993).

Casarin (2008) has implemented a practice to construct terraces associated with the water retention basin, in order to control erosion in the stretch of a road in the western region of São Paulo state, which showed positive results for the contention of storm water and decreased the silting effect downstream in areas of water recharge.

However, the cost of building and maintaining a terrace system, as well as the construction of water retention basins is relatively high, so it is recommended to make a diagnosis of the site for the deployment of these techniques in the most effective way (BERTOLINI, 1993).

Thus, the deployment of conservation practices is essential for soil and water conservation. However, an important factor for the adoption and its continuation is the profitability of the soil and water conservation (SWC) measures for the farm household. If farmers have a prospect of gaining longterm financial benefits (e.g. increased production, reduced labor input, higher off-farm income) they will be more motivated to actually adopt, maintain and replicate the measures (OSUNA et al., 2014).

These results benefit the process of planning and the management of Capão Bonito National Forest and the surrounding areas, because they allow to identify where the deployment of soil conservation 
practices are more important to promote soil and water conservation, as well as assist in choosing which practices can be adopted.

\section{Priority areas for forest restoration in a permanent preservation area of watercourses}

Riparian buffers are known to mitigate hydrologic losses of nutrients and other contaminants as they exit agricultural fields but also can intercept contaminants in surface and groundwater flows as also the buffer tree canopy itself can interact directly with contaminants in the atmosphere, contributing to the water conservation (RICE et al., 2016).

In Quanda watershed, in San Jose de Lourdes municipality of Peru, upper watershed deforestation for small-scale cattle ranching, conventional agriculture, coffee plantations, and timber extraction is predominantly responsible for reduced water quality (AGUIRRE, 2011). The quality of the downstream water supply depends directly on activities upstream, where high quality forest ecosystems, functioning water utilities and riparian forest can provide improved filtration, and reduced soil erosion and sedimentation.

The PPAs, according to the Law 12.651/2012, should be covered by native vegetation due to the benefits that a riparian forest can provide to the soil and watercourses.

However, as seen in Leal (2016), in Itanguá watershed the native vegetation is found in only $56.09 \%$ of the PPA, so there is a need to implement a forest restoration in other areas that are occupied by other uses.

It is important that the restoration of riparian areas is a local and a regional priority in tropical landscape mosaics composed of fragmented secondary forests embedded in an agricultural matrix aiming at maintaining the functionality of riparian corridors, including their roles in reducing the flow of nutrients and sediment into stream and regulating water flows (CHARÁ et al., 2007).

After the compilation of information and the creation of Table 3 , it is possible to notice that not all categories proposed in Table 1 were found.

Table 3 - Priority classes for forest restoration in a permanent preservation area along watercourses in the basin of Itanguá, Capão Bonito, SP state and their respective areas (in hectares).

Tabela 3 - Classes de prioridade para a restauração florestal na área de preservação permanente dos cursos d'água da bacia do Itanguá, Capão Bonito, SP e suas respectivas áreas (em hectares).

\begin{tabular}{|c|c|c|c|c|c|}
\hline \multirow{2}{*}{ Land use and land cover } & \multicolumn{2}{|c|}{ Declivity } & \multirow{2}{*}{ Priority } & \multirow{2}{*}{ Area (ha) } & \multirow{2}{*}{ Area $(\%)$} \\
\hline & $0-8 \%$ & $8-45 \%$ & & & \\
\hline Dirt road & - & $\mathrm{x}$ & 1 & 0.72 & 0.41 \\
\hline Temporary crop/Pasture & - & $\mathrm{x}$ & 2 & 0.64 & 0.36 \\
\hline Planted forests & - & $\mathrm{x}$ & 3 & 13.20 & 7.53 \\
\hline Dirt road & $\mathrm{x}$ & - & 4 & 3.00 & 1.71 \\
\hline Temporary crop/Pasture & $\mathrm{x}$ & - & 5 & 13.22 & 7.54 \\
\hline Planted forests & $\mathrm{x}$ & - & 6 & 39.12 & 22.30 \\
\hline Restriction & - & - & - & 105.50 & 60.15 \\
\hline Total & & & & 175.40 & 100 \\
\hline
\end{tabular}

The area occupied by restriction represents $60 \%$ of the total area, so the area that needs the implementation of a forest restoration accounts for about $40 \%$ of the PPA, being mainly made up by areas of planted forests in a region of low declivity (22.30\%). 
The thematic map created from the information plans of land cover and land use in the PPA and declivity pointed out the priority areas for forest restoration (Figure 4).

Figure 4 - Priority areas for forest restoration in a permanent preservation area of watercourses in the basin of Itanguá, Capão Bonito, SP state.

Figura 4 - Áreas prioritárias para a restauração florestal na área de preservação permanente dos cursos d'água na bacia do Itanguá, Capão Bonito - SP.

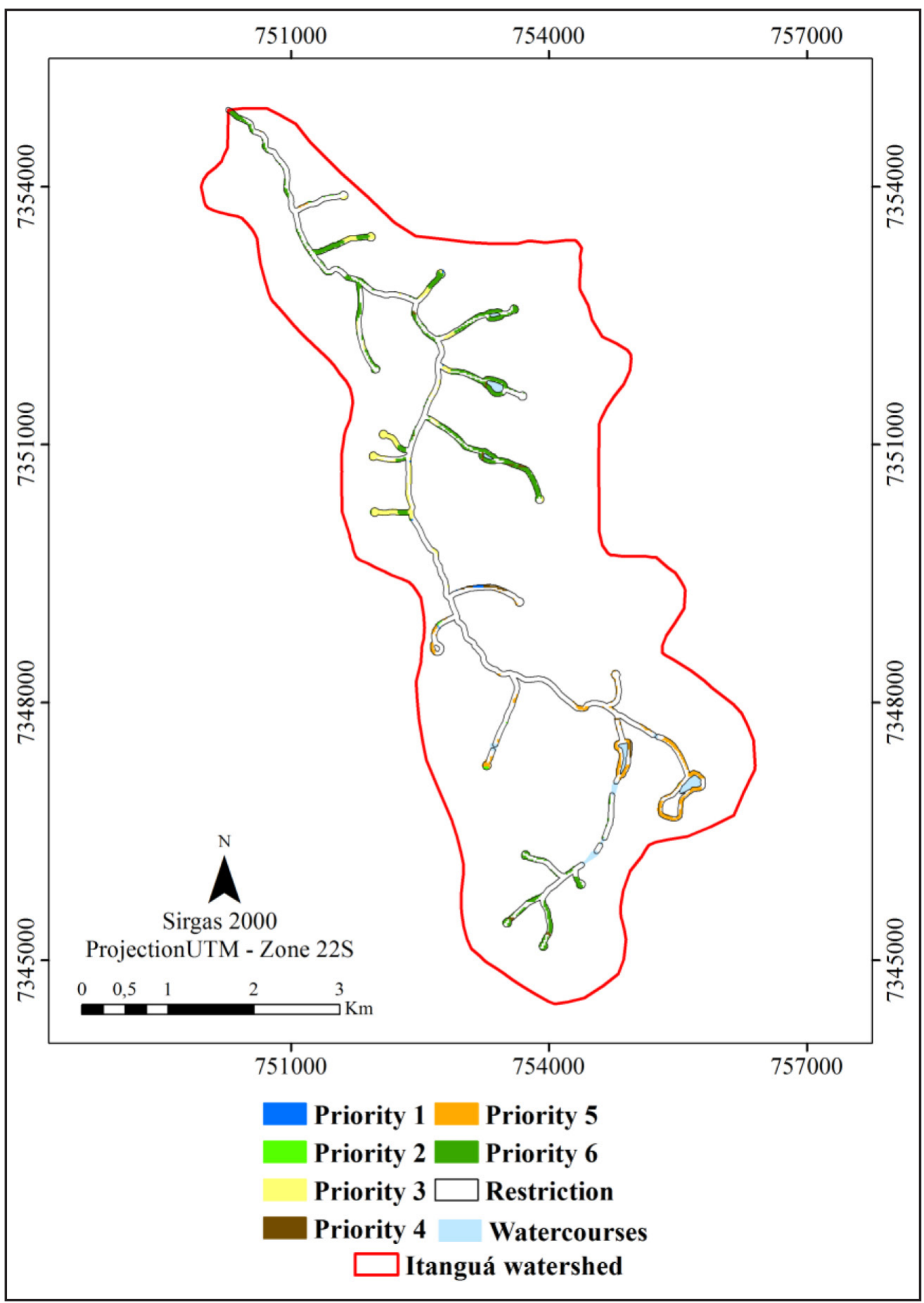

Source: Authors (2016) 
These results also help the planning process and the management of the National Forest and its vicinities in order to identify different priority levels for forest restoration in the PPA of watercourses, since it becomes infeasible to replace the current use by native vegetation throughout the area needed at once, as most of the times, the financial resources are scarce.

\section{Conclusion}

The defining for the natural resource conservation priorities can provide a significant criterion for decision making by government agencies. The conservation priority levels identified in this study indicated nine different priority classes for the implementation of conservation practices and six priority classes for forest restoration in the permanent preservation area. Areas with a dirt road in a region of higher declivity were identified as priority areas for conservation, including in permanent preservation area along watercourses in the basin. The study provides the first assessment of the land use and land cover at the basin level for Capão Bonito National Forest and hoped that identifying these areas across the whole basin will support the planning of future soil and water conservation actions.

\section{Acknowledgements}

This study was financed in part by the Coordenação de Aperfeiçoamento de Pessoal de Nível Superior - Brasil (CAPES) - Finance Code 001, Instituto Chico Mendes de Conservação da Biodiversidade (ICMBio), Capão Bonito National Forest.

\section{References}

AGÊNCIA NACIONAL DE ÁGUAS (Brasil). Programa produtor de água - manual operativo. Brasília, 2008. 60 p.

AGUIRRE, H. Campaña Orgullo en la Microcuenca Quanda: reporte final. [2011]. Disponível em: http://www.rareplanet.org/sites/rareplanet.org/files/campana_orgullo_en_quanda_-_ reporte_final_-_parte_1.pdf. Acesso em: 20 jan. 2016.

BEGER, M. et al. Integrating regional conservation priorities for multiple objectives into national policy. Nature Communications, London, v. 6, 2015. Disponível em: www.nature.com/ naturecommunications. Acesso em: 30 aug. 2018.

BERTOLINI, B. Controle de erosão em estradas rurais. Campinas: Coordenadoria de Assistência Técnica Integral, 1993. 37 p.

BERTOL, I.; SCHICK, J.; BATISTELA, O. Razão de perdas de solo e fator C para milho e aveia em rotação com outras culturas em três tipos de preparo de solo. Revista Brasileira de Ciências do Solo, Campinas, v. 26, p. 545-552, 2002.

BERTONI, J.; LOMBARDI NETO, F. Conservação do solo. São Paulo: Ícone, 1990. 355 p.

BRASIL. Ministério do Meio Ambiente. Cadastro Nacional de Unidades de Conservação. Relatórios de UC. Brasília, [2016]. Disponível em: http://www.mma.gov.br/areas-protegidas/ cadastro-nacional-de-ucs/consulta-gerar-relatorio-de-uc. Acesso em: 14 ago. 2016.

BUCHANAN, G. M.; DONALD, P. F.; BUTCHART, S. H. M. Identifying priority areas for conservation: a global assessment for forest-dependent birds. PLoS ONE, [s. l.], v. 6, n. 12, 2011.

CASARIN, R. D. Controle de erosão em estradas rurais não pavimentadas, utilizando sistema de terraceamento com gradiente associado a bacias de captação. 2008. Dissertação (Mestrado em Irrigação e Drenagem) - Universidade Estadual Paulista, Botucatu, 2008. 
CENTRO DE PESQUisAs METEREOLÓGICAS E CLIMÁticAs APLICADAS A AGRICULTURA. [Website]. [2016]. Disponível em: http://www.cpa.unicamp.br/outrasinformacoes/clima_muni_118.html. Acesso em: 03 jun. 2016.

CHARÁ, J. et al. Efecto de los corredores ribereños sobre el estado de quebradas en la zona ganadera del río La Vieja, Colombia. Agroforestería en las Américas, Turrialba, v. 45, p. 72-78, 2007.

CHAVES, H. M. L.; PIAU, L. P. Efeito da variabilidade da precipitação pluvial e do uso e manejo do solo sobre o escoamento superficial e o aporte de sedimento de uma bacia hidrográfica do Distrito Federal. Revista Brasileira de Ciências do Solo, Campinas, v. 32, p. 333-343, 2008.

COGO, N. P.; LEVIEN, R.; SCHWARZ, R. A. Perdas de solo e água por erosão hídrica influenciadas por métodos de preparo, classes de declive e níveis de fertilidade do solo. Revista Brasileira de Ciências do Solo, Campinas, v. 27, p. 743-753, 2003.

EASTMAN, J. R. Decision support: decision strategy analysis. In: IDRIS 32 release 2: guide to GIS and image processing. Worcester: Clark University, 2001. v. 2, p. 1-22.

IBGE. Manual técnico de uso da terra. 3. ed. Rio de Janeiro, 2013. 171 p.

INTERNATIONAL UNION FOR CONSERVATION OF NATURE AND NATURAL RESOURCES. Red list of threatened species. [2013]. Disponível em: http://www.iucnredlist.org/ details/32975/0. Acesso em: 10 jun. 2016.

LEAL, M. S. Caracterização da bacia do córrego Itanguá como suporte à gestão da Floresta Nacional de Capão Bonito, SP visando à conservação da água. 2016. Dissertação (Mestrado em Planejamento e Uso dos Recursos Renováveis) - Universidade Federal de São Carlos, Sorocaba, 2016.

LIU, Y. et al. Identifying priority areas for the conservation of ecosystem services using gis-based multicriteria evaluation. Polish Journal of Ecology, Wilcza, v. 61, p. 415-430, 2013.

MULLER, M. M. L. et al. Degradação de pastagens na Região Amazônica: propriedades físicas do solo e crescimento de raízes. Pesquisa Agropecuária Brasileira, Brasília, v. 36, n. 11, p. 1409$1418,2001$.

OKI, V. K. Impactos da colheita de Pinus taeda sobre o balanço hídrico, a qualidade da água e a ciclagem de nutrientes em microbacias. 2002. Dissertação (Mestrado em Ciências Florestais) - Escola Superior de Agricultura “Luiz de Queiroz”, Universidade de São Paulo, Piracicaba, 2002.

OSUNA, V. R. et al. Priority areas for watershed service conservation in the Guapi-Macacu region of Rio de Janeiro, Atlantic Forest, Brazil. Ecological Processes, [s. l.], v. 3, n. 16, p. 06-16, 2014.

RAMALHO FILHO, A.; BEEK, K. L. Sistema de avaliação da aptidão agrícola das terras. 3. ed. rev. Rio de Janeiro: Embrapa; CNPS, 1995. 65 p.

RICE, C. P. et al. Role of riparian areas in atmospheric pesticide deposition and its potential effect on water quality. Journal of the American Water Resources Association, [s. l.], v. 52, n. 5, p. 1109-1120, 2016.

ROSA, F. S.; TONELLO, K. C.; LOURENÇO, R. W. Eleição de áreas prioritárias para pagamento por serviços ambientais: uma análise em nível de microbacia. Revista Ambiente \& Água, Taubaté, v. 11, n. 2, p. 448-461, 2016.

SCHICK, J. et al. Erosão hídrica em cambissolo húmico alumínico submetido a diferentes sistemas de preparo e cultivo do solo: I. perdas de solo e água. Revista Brasileira de Ciências do Solo, Campinas, v. 24, p. 427-436, 2000. 
SCHIEVENIN, D. F. Avaliação da regeneração natural em sub-bosque de plantios de Pinus elliottii Engelm. e Araucaria angustifolia (Bertol.) Kuntze em Capão Bonito - SP. 2013. Trabalho de Conclusão de Curso (Engenharia Florestal) - Universidade Federal de São Carlos, Sorocaba, 2013.

SHI, Z. H. et al. Soil conservation planning at the small watershed level using RUSLE with GIS: a case study in the Three Gorge Area of China. Catena, [s. l.], v. 55, p. 33-48, 2004.

SILVA, A. M.; SCHULZ, H. E; CAMARGO, P. B. Erosão e hidrossedimentologia em bacias hidrográficas. São Carlos: RiMa, 2003. 140 p.

TAMBOSI, L. R. et al. A framework to optimize biodiversity restoration efforts based on habitat amount and landscape connectivity. Restorotion Ecology, [s. l.], v. 22, n. 2, p. 169-177, 2014.

WILSON, K. A. et al. Prioritizing global conservation efforts. Nature, London, v. 440, p. 337-340, 2006. 